\title{
A DISCIPLINA DA COISA JULGADA NO NCPC: ALTERAÇÕES E IMPACTOS PARA O DIREITO TRIBUTÁRIO E O RECURSO EXTRAORDINÁRIO N. 949.297
}

\author{
Marcos Vinícius Passarelli Prado \\ Paulo de Figueiredo Ferraz Pereira Leite
}

\section{INTRODUÇÃO}

A Lei n. 13.105/2015 (Novo Código de Processo Civil - NCPC), que entrou em vigor neste ano de 2016, trouxe diversas alterações na disciplina de variadas matérias. Dentre as alterações promovidas, o presente artigo tem como objeto analisar as que impactaram a disciplina da coisa julgada, bem como quais foram os impactos relevantes para o direito tributário, especialmente em relação aos limites temporais nas relações continuativas, considerando que esse tema foi objeto de reconhecimento de repercussão geral nos autos do Recurso Extraordinário (RE) n. 949.297.

\section{ALTERAÇÕES NA DISCIPLINA GERAL SOBRE A COISA JULGADA}

Ao analisarmos os art. 502 a 508 do NCPC, que trazem a disciplina geral acerca da coisa julgada, em comparação com os art. 467 a 474 do Código de Processo Civil de 1973 (CPC/73), não sobressaem alterações relevantes. O art. 502 passou a denominar a "coisa julgada [...] a autoridade [em vez de eficácia] que torna imutável e indiscutível a decisão [em vez de sentença] de mérito não mais sujeita a recurso" (grifos nossos).

A substituição de eficácia por autoridade continua predicando a sentença, sem efeitos práticos relevantes a nosso entender. A substituição de sentença por 
decisão, por sua vez, reconhece que (i) as decisões interlocutórias também podem julgar o mérito da disputa e (ii) na hipótese do art. 1.013, $\int 3^{\circ},{ }_{1}$ se a sentença não julgar o mérito, o acórdão poderá fazê-lo. No final do dispositivo, a redação foi alterada para não mais relacionar a definitividade de uma decisão ao recurso ordinário ou extraordinário, mas apenas a recurso de maneira geral, o que, apesar de produzir poucos impactos práticos, reforça a ideia de que coisa julgada está vinculada ao julgamento definitivo do mérito de um litígio, independentemente da natureza processual do ato decisório.

$\mathrm{O}$ art. 503 tem redação semelhante à do art. 468 do CPC/73; no entanto, traz uma importante alteração: o que delimita a coisa julgada é apenas a "questão principal expressamente decidida". A previsão do NCPC, da forma como vemos, fez bem ao acompanhar a evolução doutrinária ${ }^{2}$ sobre o assunto, no sentido de que a lide não delimita a coisa julgada, mas apenas a questão que restou decidida, pois o que é objeto da coisa julgada é a decisão judicial, e não o pedido.

Outra alteração promovida pelo art. 503 deve ser analisada em conjunto com o art. 504 e diz respeito às questões incidentais. Atendendo aos critérios de economia processual e prioridade ao contraditório que pautam todo o NCPC e em razão da extinção da ação declaratória incidental, o $\int 1^{\circ}$ do art. 503, de forma semelhante ao que previa o art. 470 do $\mathrm{CPC} / 73$, prescreve que a questão prejudicial expressamente decidida será objeto de coisa julgada desde que: (i) dela dependa o julgamento do mérito; (ii) a seu respeito tenha havido contraditório prévio e efetivo; e (iii) o juízo tenha competência em razão da matéria e da pessoa para resolvê-la como questão principal.

1 "Art. 1.013 [...] § 30 Se o processo estiver em condições de imediato julgamento, o tribunal deve decidir desde logo o mérito quando: I - reformar sentença fundada no art. 485; II - decretar a nulidade da sentença por não ser ela congruente com os limites do pedido ou da causa de pedir; III - constatar a omissão no exame de um dos pedidos, hipótese em que poderá julgá-lo; IV decretar a nulidade de sentença por falta de fundamentação."

2 Neste sentido: "É o objeto da sentença que determina os limites objetivos da coisa julgada, restando ao objeto do processo uma influência meramente indireta, à medida que delimita a matéria a ser apreciada na sentença, e relativa, pois a sentença e, em consequência, a coisa julgada, podem ter conteúdo distinto. [...] Em realidade, ficarão abrangidas pelos limites objetivos da coisa julgada as causas de pedir que forem efetivamente apreciadas na sentença. [...] Na mesma linha, caso a sentença seja omissa a respeito de uma das causas de pedir em processo com cumulação de causas, a coisa julgada não impedirá a propositura de nova demanda em que se invoque a causa petendi omitida" (LOPES, Bruno Carrilho Vasconcelos. Limites objetivos e eficácia preclusiva da coisa julgada. São Paulo: Saraiva. 2012. p. 19). 
Os art. 505 a 508, por sua vez, mantiveram redação semelhante à dos art. 471 a 474 do CPC/73 e a disciplina sobre: (i) a coisa julgada nas relações de trato continuado, em que a parte pode pedir a revisão da sentença se sobrevier alteração no estado de fato ou de direito (art. 505); (ii) os limites subjetivos da coisa julgada, aplicando-se às partes em litígio e não prejudicando terceiros (art. 506); (iii) a impossibilidade de rediscussão de matérias já decididas que foram objeto de preclusão (art. 507); e (iv) a impossibilidade de posterior dedução de alegações e defesas visando ao acolhimento ou à rejeição do pedido que poderiam ter sido feitos no decorrer no processo (art. 508).

As principais alterações no que diz respeito ao presente estudo, no entanto, encontram-se, na forma como vemos, na disciplina dos meios disponíveis para impugnação da coisa julgada.

\section{ALTERAÇÕES NA DISCIPLINA SOBRE OS MEIOS DE IMPUGNAÇÃO DA COISA JULGADA}

\subsection{Impugnação ao cumprimento de sentença no NCPC}

Ao tratar da impugnação ao cumprimento de sentença e da impugnação ao cumprimento de sentença contra a Fazenda Pública, os art. 525 e 535 alteraram bastante a disciplina anterior sobre a inexigibilidade do título. Como as redações dos dispositivos são equivalentes, vamos transcrever apenas os dispositivos relativos à execução contra a Fazenda Pública, mas já ressaltando que os comentários e as conclusões se aplicam aos dois casos.

Com efeito, o art. 741, parágrafo único, do CPC/73 (que tratava dos embargos à execução contra a Fazenda Pública) previa que:

Para efeito do disposto no inciso $\mathrm{II}^{3}$ do caput deste artigo, considera-se também inexigível o título judicial fundado em lei ou ato normativo declarados inconstitucionais pelo Supremo Tribunal Federal, ou fundado em aplicação ou interpretação da lei ou ato normativo tidas pelo Supremo Tribunal Federal como incompatíveis com a Constituição Federal.

O art. 535 do NCPC, por sua vez, se aprofundou mais em relação a esse tema ao prever que:

3 "II - inexigibilidade do título; [...]." 
$\int 5^{\circ}$ Para efeito do disposto no inciso $\mathrm{III}^{4}$ do caput deste artigo, considera-se também inexigível a obrigação reconhecida em título executivo judicial fundado em lei ou ato normativo considerado inconstitucional pelo Supremo Tribunal Federal, ou fundado em aplicação ou interpretação da lei ou do ato normativo tido pelo Supremo Tribunal Federal como incompatível com a Constituição Federal, em controle de constitucionalidade concentrado ou difuso.

$\int 6^{\circ}$ No caso do $\int 5^{\circ}$, os efeitos da decisão do Supremo Tribunal Federal poderão ser modulados no tempo, de modo a favorecer a segurança jurídica.

$\int 7^{\circ} \mathrm{A}$ decisão do Supremo Tribunal Federal referida no $\int 5^{\circ}$ deve ter sido proferida antes do trânsito em julgado da decisão exequenda.

$\int 8^{\circ}$ Se a decisão referida no $\int 5^{\circ}$ for proferida após o trânsito em julgado da decisão exequenda, caberá ação rescisória, cujo prazo será contado do trânsito em julgado da decisão proferida pelo Supremo Tribunal Federal.

A atual disciplina adequou-se ao entendimento do Superior Tribunal de Justiça $(\mathrm{STJ})^{5}$ proferido em sede de recurso repetitivo sobre o dispositivo semelhante do

4 "III - inexequibilidade do título ou inexigibilidade da obrigação; [...]."

5 "PROCESSUAL CIVIL E ADMINISTRATIVO. RECURSO ESPECIAL REPRESENTATIVO DE CONTROVÉRSIA. ART. 543-C DO CPC E RESOLUÇÃO STJ N. ${ }^{\circ}$ 08/2008. FGTS. EXPURGOS. SENTENÇA SUPOSTAMENTE INCONSTITUCIONAL. EMBARGOS À EXECUÇÃO. ART. 741, PARÁGRAFO ÚNICO, DO CPC. EXEGESE. INAPLICABILIDADE ÀS SENTENÇAS SOBRE CORREÇÃO MONETÁRIA DO FGTS. EXCLUSÃO DOS VALORES REFERENTES A CONTAS DE NÃO-OPTANTES. ARESTO FUNDADO EM INTERPRETAÇÃO CONSTITUCIONAL E MATÉRIA FÁTICA. SÚMULA 7/STJ. 1. O art. 741, parágrafo único, do CPC, atribuiu aos embargos à execução eficácia rescisória de sentenças inconstitucionais. Por tratar-se de norma que excepciona o princípio da imutabilidade da coisa julgada, deve ser interpretada restritivamente, abarcando, tão somente, as sentenças fundadas em norma inconstitucional, assim consideradas as que: (a) aplicaram norma declarada inconstitucional; (b) aplicaram norma em situação tida por inconstitucional; ou (c) aplicaram norma com um sentido tido por inconstitucional. 2. Em qualquer desses três casos, é necessário que a inconstitucionalidade tenha sido declarada em precedente do STF, em controle concentrado ou difuso e independentemente de resolução do Senado, mediante: (a) declaração de inconstitucionalidade com ou sem redução de texto; ou (b) interpretação conforme a Constituição. 3. Por consequência, não estão abrangidas pelo art. 741, parágrafo único, do CPC as demais hipóteses de sentenças inconstitucionais, ainda que tenham decidido em sentido diverso da orientação firmada no STF, tais como as que: (a) deixaram de aplicar norma declarada constitucional, ainda que em controle concentrado; (b) aplicaram dispositivo da Constituição que o STF considerou sem auto-aplicabilidade; (c) deixaram de aplicar dispositivo da Constituição que o STF considerou auto-aplicável; e (d) aplicaram preceito normativo que o STF considerou revogado ou não recepcionado. 4. 
CPC/73 (art. 741, parágrafo único) ao prever que a decisão do Supremo Tribunal Federal (STF) que resulta na inexequibilidade do título deve ser proferida em controle concentrado ou difuso de constitucionalidade $\left(\mathbb{S} 5^{\circ}\right)$ e anterior ao trânsito em julgado da decisão exequenda $\left(\mathbb{\Omega} 7^{\circ}\right)$.

A principal alteração, entretanto, ocorreu na previsão introduzida pelo $\int 8^{\circ}$, que criou um novo termo inicial para a contagem do prazo de dois anos para o ajuizamento da ação rescisória. O art. 975 do NCPC manteve o prazo de dois anos para a propositura da ação rescisória anteriormente previsto no art. 495 do CPC/73 e alterou o termo inicial desse prazo do trânsito em julgado da decisão rescindenda para o trânsito em julgado da última decisão proferida no processo, prevendo como exceções: (i) decisão fundada em prova falsa, situação na qual o termo inicial do prazo será a data de descoberta da prova nova, observado o prazo máximo de cinco anos contado do trânsito em julgado da última decisão proferida no processo; (ii) decisão fundada em simulação ou de colusão das partes, situação na qual o prazo começa a contar, para o terceiro prejudicado e para o Ministério Público, quando não houver intervindo no processo, a partir do momento que tiverem ciência da simulação ou da colusão.

Assim, somos da opinião de que o $\int 8^{\circ}$ do art. 535 , bem como o $\int 15^{\circ}$ do art. 525, instituem nova exceção em relação ao termo inicial da contagem do prazo para a rescisória sem qualquer limitação temporal. A fim de possibilitar a aferição da validade desse dispositivo, porém, é necessário antes analisar a disciplina atual acerca da ação rescisória.

\subsection{Ação rescisória no NCPC}

$\mathrm{O}$ art. 966 do NCPC tem redação bastante semelhante à do art. 485 do CPC/73, excluindo apenas uma hipótese que autoriza o ajuizamento ("fundamento para invalidar confissão, desistência ou transação em que se baseou a sentença"):

Art. 966. A decisão de mérito, transitada em julgado, pode ser rescindida quando:

I - se verificar que foi proferida por força de prevaricação, concussão ou corrupção do juiz;

Também estão fora do alcance do parágrafo único do art. 741 do CPC as sentenças cujo trânsito em julgado tenha ocorrido em data anterior à vigência do dispositivo. [...] 7. Recurso especial conhecido em parte e não provido. Acórdão sujeito ao regime do art. 543-C do CPC e da Resolução STJ n. ${ }^{\circ}$ 08/2008” (REsp n. 1189619/PE, Rel. Min. Castro Meira, $1^{\text {a }}$ Seção, julgado em: 25 ago. 2010, DJe: 2 set. 2010, grifos nossos). 
II - for proferida por juiz impedido ou por juízo absolutamente incompetente;

III - resultar de dolo ou coação da parte vencedora em detrimento da parte vencida ou, ainda, de simulação ou colusão entre as partes, a fim de fraudar a lei; IV - ofender a coisa julgada;

V - violar manifestamente norma jurídica;

VI - for fundada em prova cuja falsidade tenha sido apurada em processo criminal ou venha a ser demonstrada na própria ação rescisória;

VII - obtiver o autor, posteriormente ao trânsito em julgado, prova nova cuja existência ignorava ou de que não pôde fazer uso, capaz, por si só, de lhe assegurar pronunciamento favorável;

VIII - for fundada em erro de fato verificável do exame dos autos.

Como ocorrido com o art. 502, o caput do art. 966 substituiu a previsão de rescisão da sentença de mérito pela decisão de mérito, sem outras alterações. As hipóteses de rescisão previstas nos incisos, salvo a já mencionada hipótese excluída, permanecem as mesmas com apenas algumas alterações de redação em alguns casos.

Dentre as hipóteses previstas, a nosso ver a que gera mais impactos para o direito tributário é a descrita no inciso $\mathrm{V}$ (decisão que "violar manifestamente norma jurídica" em substituição à decisão que "violar literal disposição de lei” art. 485, inciso V, do CPC/73), tendo em vista embasar o ajuizamento de ação rescisória em caso de decisão posterior do STF em sentido diverso da decisão que transitou em julgado. A alteração na redação apenas incorporou a interpretação que a doutrina majoritária realizava a partir do dispositivo do CPC/73 no sentido de que "disposição de lei" deveria ser entendida como norma jurídica ${ }^{6}$ e substituiu

6 Neste sentido: "O direito, e não a lei como texto, é o que se teme seja ofendido. Alguns escritores desavisados leram 'direito expresso' como se fosse 'lei escrita clara', 'lei escrita explícita'. É grave erro. O direito de que se fala é o direito em sua consistência de revelação" (MIRANDA, Pontes de. Comentários ao Código de Processo Civil. Tomo VI. 3. ed. rev. e aum. Rio de Janeiro: Forense, 1998. p. 218); "o vocábulo lei empregado no art. 485, V, deve ser compreendido no seu mais lato senso, entendendo-se proferida contra legem a sentença definitiva contra o teor do direito escrito, de que natureza seja, material ou processual” (TUCCI, Rogério Lauria. Juiz natural, competência recursal, preclusão pro indicato, violação de literal disposição de lei e ação rescisória. Revista dos Tribunais, v. 94 , n. 838 , ago. 2005 , p. 145). 
a expressão "violação a literal disposição" por "violação manifesta" para adotar uma nova nomenclatura, sem efeitos relevantes.

A principal alteração sobre esse tema, no entanto, não foi introduzida nos artigos que disciplinam a ação rescisória no NCPC, mas nos já mencionados art. 525, $\llbracket 15^{\circ}$, e $535, \int 8^{\circ}$, que prescrevem que a declaração de inconstitucionalidade da lei que serviu de fundamento para uma decisão, em controle difuso ou concentrado, é justificativa para o ajuizamento de ação rescisória, bem como que, nessa hipótese, o prazo de dois anos será contado a partir do trânsito em julgado da decisão do STF.

\subsubsection{Art. 525, $\S 15^{\circ}$, e 535, $\S 8^{\circ}$, e a instituição de nova hipótese e de novo termo inicial para ação rescisória}

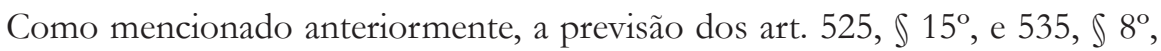
do NCPC é inédita e institui nova hipótese de ajuizamento de ação rescisória, bem como termo inicial indefinido para o prazo de dois anos para o seu ajuizamento, que se consubstancia, ao final, em condicionamento ad aeternum da coisa julgada a uma eventual e futura decisão do STF.

Justamente por isso, surgiram vários posicionamentos doutrinários em relação à sua (in)validade:

i. Nelson Nery Jr. e Rosa Maria de Andrade Nery ${ }^{7}$ defendem que, se já tiver transcorrido o prazo decadencial para o ajuizamento da ação rescisória, esse prazo não pode ser reaberto, sob pena de violação à segurança jurídica e à garantia da intangibilidade da coisa julgada. Assim, a única interpretação constitucional do dispositivo seria a de que "somente pode ser iniciado o prazo da rescisória a partir do trânsito em julgado da decisão do STF, se ainda não tiver sido extinta a pretensão rescisória cujo prazo tenha-se iniciado do trânsito em julgado da decisão exequenda".

ii. Alexandre Freitas Câmara ${ }^{8}$ defende que haja uma limitação temporal para o termo inicial do prazo decadencial e propõe aplicação analógica do art. 205 do Código Civil, que trata do limite máximo dos prazos prescricionais, para que o direito à rescisão apenas possa ser exercido no prazo máximo de dez anos após o trânsito em julgado da última decisão proferida no processo.

7 NERY JR., Nelson; NERY, Rosa Maria de Andrade. Código de Processo Civil comentado. 2. ed. em e-book baseada na 16. ed. impressa. São Paulo: Revista dos Tribunais, 2016.

8 CÂMARA, Alexandre Freitas. O novo processo civil brasileiro. 2. ed. São Paulo: Atlas, 2016. p. 477. 
iii. Heitor Sica e Rodrigo Barioni, ${ }^{9-10}$ em linha semelhante à anterior, propõem que se adote o mesmo prazo máximo de cinco anos do trânsito em julgado da última decisão proferida no processo adotado para o descobrimento de prova nova (art. 975, $₫ 2^{\circ}$, do NCPC).

iv. Cassio Scarpinella ${ }^{11}$ defende a inconstitucionalidade formal dos dispositivos por violação ao art. 65 da Constituição, por se tratar de regra acrescentada apenas na revisão do texto antes do envio à sanção presidencial. Entende, no entanto, que materialmente a regra introduzida pelo NCPC seria constitucional. ${ }^{12}$

v. Humberto Theodoro Junior ${ }^{13}$ não opõe críticas aos dispositivos, entendendo que o prazo para o ajuizamento da ação rescisória realmente começaria a fluir a partir do trânsito em julgado da decisão do STF.

Dentre as posições apresentadas - esclarecendo que não nos propomos à análise acerca da regularidade do processo legislativo -, concordamos com aquela defendida por Nelson e Rosa Nery, pois a prescrição normativa dos art. 525, $\mathbb{\int} 15^{\circ}$, e $535, \int 8^{\circ}$, acaba por instituir situação de imprevisibilidade e indefinição, que não se coaduna com a ideia de segurança jurídica da qual, conforme já esclarecido por Geraldo Ataliba e Humberto Ávila, ${ }^{14-15}$ a coisa julgada é uma manifestação.

9 SICA, Heitor Vitor Mendonça. Comentários de Heitor Vitor Mendonça Sica. In: CABRAL, Antonio do Passo; CRAMER, Ronaldo (Coord.). Comentários ao novo Código de Processo Civil. 2. ed. rev., atual. e ampl. Rio de Janeiro: Forense, 2016. p. 833.

10 BARIONI, Rodrigo. In: WAMBIER, Teresa Arruda Alvim et. al. (Coord.). Breves comentários ao Código de Processo Civil. 2. ed. rev. e atual. São Paulo: Revista dos Tribunais, 2016. p. 2276.

11 BUENO, Cassio Scarpinella. Manual de direito processual civil: inteiramente estruturado à luz do novo CPC - Lei n. 13.105, de 16-3-2015. São Paulo: Saraiva, 2015.

12 BUENO, Cassio Scarpinella. Novo Código de Processo Civil anotado. São Paulo: Saraiva, 2015.

13 THEODORO JUNIOR, Humberto. Curso de direito processual civil: execução forçada, processo nos tribunais, recursos e direito intertemporal. 48. ed. rev., atual. e ampl. Rio de Janeiro: Forense, 2016. v. 3.

14 "O quadro constitucional que adota os padrões do constitucionalismo [...] de instituições republicanas [...] postula absoluta e completa previsibilidade da ação estatal pelos cidadãos e administrados" (ATALIBA, Geraldo. República e Constituição. 2. ed. São Paulo: Malheiros, 2007. p. 171).

15 "O que posso dizer é que a segurança jurídica, na teoria que estou aqui defendendo, é um princípio que exige, dos Poderes Legislativo, Executivo e Judiciário, a adoção de comportamentos que contribuam para a existência, em benefício dos cidadãos e na sua perspectiva, de um estado de confiabilidade e de calculabilidade do Direito, com base na sua cognoscibilidade, por meio da controlabilidade do jurídico-racional de estruturas argumentativas, com instrumento garantidor 
Afinal, a coisa julgada é um dos instrumentos assegurados pela Constituição para a concretização da segurança jurídica ao evitar que as demandas judiciais se perpetuem e garantir uma resposta aos jurisdicionados, cuja observância é obrigatória. Assim, as hipóteses que a excepcionam, como a ação rescisória, devem ser interpretadas restritivamente.

Por isso, entendemos que a hipótese descrita no inciso V do art. 966 apenas autoriza o ajuizamento de ação rescisória se a decisão do STF transitar em julgado antes da decisão do caso concreto ou no decorrer do prazo da ação rescisória. E a razão para tanto é simples: não se pode afirmar que haveria violação manifesta à norma jurídica antes do pronunciamento do STF sobre essa mesma norma.

Admitir-se a ação rescisória como proposto pelos art. $525, \llbracket 15^{\circ}$, e $535, \mathbb{8} 8^{\circ}$, do NCPC significa, ao final, ajuizamento de ação rescisória com fundamento em direito superveniente, ${ }^{16}$ o que não só não encontra previsão no sistema jurídico brasileiro como, ainda, não pode produzir efeito retroativo sobre a coisa julgada. ${ }^{17}$ É com base nesse entendimento, a propósito, que o STF já decidiu que a ação rescisória não se destina à uniformização de jurisprudência:

AÇÃO RESCISÓRIA VERSUS UNIFORMIZAÇÃO DA JURISPRUDÊNCIA. O Direito possui princípios, institutos, expressões e vocábulos com sentido próprio, não cabendo colar a sinonímia às expressões “ação rescisória" e "uniformização da jurisprudência". AÇÃO RESCISÓRIA - VERBETE No 343 DA SÚMULA DO SUPREMO. O Verbete $n^{\circ}$ 343 da Súmula do Supremo deve de ser observado em situação jurídica na qual, inexistente controle concentrado de constitucionalidade, haja entendimentos diversos sobre o alcance da norma, mormente quando o Supremo tenha sinalizado, num primeiro passo, óptica coincidente com a revelada na

do respeito à sua capacidade de - sem engano, frustração, surpresa e arbitrariedade - plasmar digna e responsavelmente o seu presente e fazer um planejamento estrategicamente informado do seu futuro" (ÁVILA, Humberto. Segurança juridica: uma teoria estrutural. In: SCHOUERI, Luís Eduardo; BIANCO, João Francisco (Coord.). Estudos de direito tributário em homenagem ao prof. Gerd Willi Rothmann. São Paulo: Quartier Latin, 2016. p. 643-644).

Nesse sentido, tem-se "O direito superveniente tem como limite temporal o momento do encerramento da discussão" (GRINOVER, Ada Pellegrini. Direito Superveniente. Repercussão sobre o ato judicial. Momento de eficácia da decisão. In: O processo: estudos e pareceres. 2. ed. rev. e ampl. São Paulo: DPJ, 2009, p. 586-588).

17 SARLET, Ingo Wolgfang; MARINONI, Luiz Guilherme; MITIDIERO, Daniel. Curso de Direito Constitucional. 2. ed. rev. atual. e ampl. São Paulo: Revista dos Tribunais, 2013. 
decisão rescindenda. (RE n. 590809, Rel. Min. Marco Aurélio, Tribunal Pleno, Repercussão Geral - Mérito, DJe: 24 nov. 2014, grifo nosso)

Esclarecidas as razões pelas quais entendemos serem inconstitucionais as mencionadas previsões do NCPC, passamos à análise de um desdobramento da discussão que assume maior relevância para o direito tributário: a coisa julgada nas relações "continuativas" ou "de trato continuado".

\section{A COISA JULGADA NAS RELAÇÕES CONTINUATIVAS}

\subsection{Limites "temporais" da coisa julgada}

O dispositivo legal que prescreve os limites "temporais" da coisa julgada é o art. 505 do NCPC, que manteve a redação do art. 471, inciso I, do CPC/73:

Art. 505. Nenhum juiz decidirá novamente as questões já decididas relativas à mesma lide, salvo:

I - se, tratando-se de relação jurídica de trato continuado, sobreveio modificação no estado de fato ou de direito, caso em que poderá a parte pedir a revisão do que foi estatuído na sentença;

II - nos demais casos prescritos em lei.

A leitura desse dispositivo, da forma como vemos, justifica o uso das aspas ao tratarmos dos limites "temporais" da coisa julgada, na medida em que, apesar de se referir às relações jurídicas continuativas e, assim, se projetar no tempo, o art. 505 , na verdade, endereça os limites objetivos da coisa julgada ao determinar o condicionamento desta à manutenção dos estados de fato ou de direito.

Assim, deve-se, em primeiro lugar, esclarecer que as relações jurídicas continuativas são aquelas que "nascem de fatos instantâneos, mas que repercutem no tempo de maneira uniforme e repetida. São relações homogêneas ou reiteradas, decorrentes de comportamentos de mesmo gênero, quando a conduta-padrão tenha sido decidida no primeiro processo". ${ }^{18}$ A partir desse esclarecimento, constata-se que, ao permitir que o juiz aprecie novamente as questões decididas sobre

18 CABRAL, Antonio do Passo. Coisa julgada e preclusões dinâmicas: entre continuidade, mudança e transição de posições processuais estáveis. Salvador: Juspodivm, 2013. p. 499. 
a mesma lide quando sobrevierem alterações nos estados de fato ou de direito, permite-se também a apreciação de uma conduta que deixou de se subsumir à conduta-padrão definida pela decisão judicial.

$\mathrm{Na}$ nossa opinião, portanto, o art. 505 erra ao afirmar que se trataria da mesma lide. Afinal, as alterações nos estados de fato ou de direito, quando aptas a dar ensejo a uma nova causa de pedir e um novo pedido, resultam na formação de uma nova relação jurídica, ainda que entre as mesmas partes e envolvendo objeto semelhante. ${ }^{19}$

Nessa perspectiva, um provimento declaratório não alcança fatos ainda não ocorridos, mas uma relação atual e permanente, projetando-se para o futuro. $\mathrm{O}$ dispositivo da decisão de natureza declaratória define um regime jurídico para uma conduta-padrão, na qual se enquadram relações jurídicas reiteradas entre as mesmas partes. Por isso, não há de se argumentar que a coisa julgada não pode projetar efeitos para o futuro. ${ }^{20}$

Há como se concluir a partir do art. 505 do NCPC, portanto, que a parte não submete uma mesma questão à reapreciação, ${ }^{21}$ trata-se, na verdade, da apreciação inédita de outro objeto, pois houve alteração da relação jurídica que justificou nova análise pelo poder judiciário; é um novo regime jurídico para uma nova relação jurídica entre as mesmas partes. Assim, confere autorização às partes para requererem o reconhecimento de que a modificação nos estados de fato ou de direito estabeleceu um novo regime jurídico a que se submete a relação jurídica

19 Neste sentido: "A parte poderá pleitear nova sentença precisamente porque a alteração de fato ou de direito vem a estabelecer nova causa de pedir, diversa daquela em relação à qual operou a coisa julgada. [...] Não se pedirá para rever a coisa julgada anterior: formular-se-á uma nova pretensão, inconfundivel com aquela que ficou acobertada pela res iudicata" (TALAMINI, Eduardo. A coisa julgada no tempo (os "limites temporais" da coisa julgada). Revista do Advogado, v. 26, n. 88, São Paulo, 2006, p. 58).

20 FERRAZ JR., Tercio Sampaio. Direito constitucional: liberdade de fumar, privacidade, estado, direitos humanos e outros temas. Barueri: Manole, 2007.

21 "Sobrevindo modificação no estado de fato ou de direito, a regra ditada pela sentença pode ser revista, mediante ação da parte interessada, para se adaptar à situação superveniente. Isto, é claro, não atinge a coisa julgada que permanecerá intocável nos seus limites objetivos, vinculada à relação jurídica tal como se apresentou no momento da decisão" (ARAÚJO CINTRA, Antonio Carlos de. Comentários ao Código de Processo Civil. Rio de Janeiro: Forense. 2000. p. 304. v. 4: arts. 332 a 475). 
"continuativa" que foi objeto de decisão judicial anterior, ultrapassando os limites objetivos da coisa julgada existente para aquela relação. ${ }^{22}$

Considerando o objeto do presente estudo e, ainda, tendo em vista que as alterações no estado de fato, em tese, estão propensas a gerar menor discussão, passemos a focar nossos comentários apenas na modificação no estado de direito.

\subsection{Alteração no estado de direito}

As alterações legislativas representam, como não poderia deixar de ser, uma modificação no sistema jurídico, pois trazem novos enunciados prescritivos ao sistema. Da mesma forma, a decisão proferida em sede de controle concentrado de constitucionalidade também representa alteração no estado de direito na medida em que reconhece a (in)compatibilidade de uma norma jurídica com a Constituição e, por consequência, sua aptidão para regular condutas intersubjetivas.

No entanto, ao voltarmos as atenções ao art. 505, inciso I, do NCPC, verificamos que não é qualquer alteração legislativa ou decisão proferida em sede de controle concentrado de constitucionalidade que configura uma modificação no estado de direito apta a permitir a revisão da coisa julgada ao juiz. Isso porque a modificação no estado de direito que permite esse pedido deve trazer um novo regime jurídico à relação, de forma a não mais se cogitar a permanência do regramento prescrito pela norma sobre a qual incidiu a coisa julgada. ${ }^{23}$

22 Nesse sentido: "A mudança de qualquer desses elementos compromete o silogismo original da sentença, porque está alterado o silogismo do fenômeno da incidência por ela apreciado. A relação jurídica que antes existia deixou de existir, e vice-versa" (ZAVASCKI, Teori Albino. Eficácia das sentenças na jurisdição constitucional. São Paulo: Revista dos Tribunais, 2001. p. 88-89).

Em sentido aproximado: "se a relação jurídica declarada existente ou inexistente é uma relação permanente, que se projeta no futuro, ou uma relação sucessiva, como alguns caracterizam a relação jurídica tributária, exatamente porque ela se renova anualmente ou a cada nova operação sob os mesmos ou diversos pressupostos fático-juridicos, a certeza da sua existência ou inexistência perdura até que ocorra alguma modificação na situação jurídica que ensejou essa declaração, ou seja, até que ocorra algum fato novo, apto a gerar validamente uma situação jurídica diversa daquela que gerou a declaração da existência ou inexistência da relação jurídica (CPC, artigo 471, inciso I) ou que sobrevenha lei nova, que passe a dar disciplina diversa à sequência de fatos até então regulados pela coisa julgada anterior" (GRECO, Leonardo. A declaração de constitucionalidade da Lei pelo STF em controle concentrado e a coisa julgada anterior: análise do Parecer 492 da Procuradoria-Geral da Fazenda Nacional. Revista Dialética de Direito Processual, n. 114, São Paulo, 2012, p. 46). 
A respeito dos diferentes efeitos promovidos por alterações no estado de direito, esclarece Tercio Sampaio Ferraz Jr. ${ }^{24}$ que:

Um regime jurídico é sempre um sistema, isto é, conjunto de relações determinadas por regras (estrutura) e um conjunto de elementos, determinados por seus atributos (repertório). As relações são básicas ou secundárias, conforme sejam básicas ou secundárias as regras. Básicas são as regras cuja mudança altera o sentido da relação, que passa a ser outro. Secundárias são as regras cuja mudança não altera o sentido das relações.

Sob essa perspectiva, a modificação no estado de direito ocorre quando são alteradas as regras básicas (regime jurídico) que disciplinam uma relação jurídica. Trazendo essas considerações para o campo do direito tributário, entendemos, desde já, que norma que altere o prazo para pagamento de um tributo não configura modificação no estado de direito apta a permitir a revisão de decisão que havia reconhecido a inexistência da respectiva relação jurídico-tributária.

A problemática concentra-se, a nosso ver, quando as alterações normativas se operam no campo dos critérios da regra-matriz de incidência tributária, assim entendidos como os requisitos básicos para a criação de qualquer tributo. Apesar de haver situações mais e menos claras, entendemos que não é toda alteração nesses critérios que representa uma modificação no estado de direito a ultrapassar os limites objetivos da coisa julgada.

Com efeito, o primeiro passo é identificar o conteúdo da decisão que foi objeto da coisa julgada e o fundamento para justificar a invalidade na cobrança do tributo. A título ilustrativo, caso se tenha decidido que a materialidade do tributo seria inconstitucional, uma alteração normativa no critério quantitativo, sem dúvida, não representará modificação no estado de direito. Nesse sentido, entendemos que a alteração no estado de direito que permite o pedido de revisão deve necessariamente alcançar o fundamento da decisão que transitou em julgado. Apenas com uma alteração nesses termos se ultrapassariam os limites objetivos da coisa julgada e, assim, haveria autorização normativa para o pedido de revisão em exame.

É necessário, no entanto, esclarecer que se de um lado o art. 505, inciso I, do NCPC prescreve uma faculdade - na medida em que o interessado (contribuinte

24 FERRAZ JR., Tercio Sampaio. Direito constitucional: liberdade de fumar, privacidade, estado, direitos humanos e outros temas. Barueri: Manole, 2007. p. 128. 
ou Fazenda Pública) fica autorizado a recorrer ao poder judiciário para obter um provimento declarando que a coisa julgada anterior a ele não mais se aplica -, de outro, também veicula uma exigência, pois o juízo não pode apreciar a questão de ofício e é necessário um provimento judicial "superando" a coisa julgada anterior.

Deve-se ressaltar ainda que, por atenção ao princípio da segurança jurídica, os efeitos da decisão que julgar esse pedido de revisão não retroagem ao momento de ajuizamento da ação no âmbito da qual surgiu a coisa julgada, como ocorre com a ação rescisória, pois não haverá desconstituição da decisão revisada, que permanece intacta. A ação revisional busca o reconhecimento do surgimento de um novo regime jurídico e, por isso, apenas pode retroagir até a data da alteração no estado de direito, observado o prazo prescricional.

\subsection{O Recurso Extraordinário n. 949.297 e a posição defendida pelo Ministério Público Federal}

Entendemos que a posição por nós defendida no tópico anterior apresenta-se como a melhor solução para o julgamento do Recurso Extraordinário (RE) n. 949.297, submetido ao regime dos recursos extraordinários repetitivos, em que se decidirá sobre os efeitos da decisão proferida pelo STF em controle concentrado de constitucionalidade sobre a coisa julgada existente para uma relação individual em sentido contrário:

RECURSO EXTRAORDINÁRIO. REPERCUSSÃO GERAL. PRELIMINAR. RECONHECIMENTO. DIREITO TRIBUTÁRIO. CONTRIBUIÇÃO SOCIAL SOBRE O LUCRO LÍQUIDO - CSLL. LEI 7.689/88. DIREITO PROCESSUAL CIVIL. COISA JULGADA. LIMITES. INEXISTÊNCIA DE RELAÇÃO JURÍDICA. INCONSTITUCIONALIDADE INCIDENTAL. DECLARAÇÃO DE CONSTITUCIONALIDADE EM CONTROLE ABSTRATO E CONCENTRADO. ADI 15. SÚMULA 239 DO STF.

1. A matéria constitucional controvertida consiste em delimitar o limite da coisa julgada em âmbito tributário, na hipótese de o contribuinte ter em seu favor decisão judicial transitada em julgado que declare a inexistência de relação jurídico-tributária, ao fundamento de inconstitucionalidade incidental de tributo, por sua vez declarado constitucional, em momento posterior, na via do controle concentrado e abstrato de constitucionalidade exercido pelo STF. 
2. Preliminar de repercussão geral em recurso extraordinário reconhecida. (RE n. 949.297 RG, Rel. Min. Edson Fachin, DJe: 12 maio 2016, publicado em: 13 maio 2016, grifo nosso)

Discordamos, assim, do parecer proferido pelo Ministério Público Federal sobre o assunto, que propõe a fixação da seguinte tese:

A coisa julgada em matéria tributária, quando derivada de relação jurídica de trato continuado, perde sua eficácia no momento da publicação do acórdão exarado no âmbito do controle concentrado de constitucionalidade contrário ao sentido da sentença individual (art. 28 da Lei 9.868/99).

A razão para nossa discordância reside no fato de a declaração de inconstitucionalidade ocorrer no plano abstrato e, por mais que produza efeitos ex tunc, não ser capaz de desconstituir todas as relações jurídicas formadas e nela fundamentadas. ${ }^{25}$ A partir da coisa julgada, a relação jurídica passa a ser disciplinada exclusivamente pela decisão judicial proferida no caso concreto, não podendo ser atingida pelos efeitos retroativos que operaram na norma geral e abstrata, ${ }^{26}$ pois a norma concreta (decisão que transitou em julgado) tornou-se a fonte exclusiva a regulamentar a respectiva relação jurídica. ${ }^{27}$

25 Nesse sentido: "a declaração de inconstitucionalidade, por si só, jamais operará efeitos sobre todas as situações pretéritas. De modo que o Tribunal, por isso mesmo, não precisa expressamente ressalvar a coisa julgada material dos efeitos retroativos da decisão de inconstitucionalidade. A essência da coisa julgada material seria claramente negada caso a decisão de inconstitucionalidade nulificasse as decisões dos juízes e tribunais. Contudo, a coisa julgada material, por estar protegida pelo art. $5^{\circ}, \mathrm{XXXVI,} \mathrm{da} \mathrm{CF}$, assim como pelo princípio da segurança jurídica, não desaparece diante de decisão de inconstitucionalidade ou, em outras palavras, de decisão que declara a inconstitucionalidade da lei em que a decisão acobertada pela coisa julgada se fundou" (SARLET, Ingo Wolgfang; MARINONI, Luiz Guilherme; MITIDIERO, Daniel. Curso de Direito Constitucional. 2. ed. São Paulo: Revista dos Tribunais, 2013. p. 1088).

26 MOREIRA, José Carlos Barbosa. Considerações sobre a chamada "relativização" da coisa julgada material. Revista Dialética de Direito Processual, n. 22, São Paulo, p. 91-111, jan. 2005.

27 Nesse mesmo sentido: "O acertamento contido na sentença trânsita em julgado 'rompe o nexo entre a norma e a factispécie concreta, substituindo aquela na disciplina desta' [...] Com expressão tecnicamente menos precisa, mas plasticamente mais eficaz, pode dizer-se que a coisa julgada substancial opera como lex specialis, desprendendo a disciplina da norma geral e abstrata feita valer em juizo" (PROTO PISANI, Andrea. Appunti sul giudicato civile e sui suoi limiti oggettivi. Rivista di diritto processuale, v. XLV, série II, 1990, p. 389-390); "transitada em julgado, a sentença desprende-se da lei em que se gerou e vale por si mesma, baseada directamente na Constituição." 
Seguindo a mesma linha de raciocínio, o Ministro Gilmar Mendes afasta a suposta ilicitude do ato fundado em lei posteriormente declarada inconstitucional, justamente para atender ao princípio da segurança jurídica. Afirma, então, que se devem diferenciar os efeitos da decisão no plano normativo e no plano do ato singular. ${ }^{28}$ Também de acordo com essa posição, o Ministro Luís Roberto Barroso separa a retroatividade dos efeitos no plano abstrato e no plano concreto para demonstrar que não é possível a desconstituição de todas as situações jurídicas que se consolidaram antes da decisão do STF. ${ }^{29}$

Em conformidade com esse entendimento, o Ministro Celso de Mello reconheceu no julgamento do Agravo Regimental (AgRg) no RE n. 592.912 que:

a decisão do Supremo Tribunal Federal que haja declarado inconstitucional determinado diploma legislativo em que se apóie o ato sentencial transitado em julgado, ainda que impregnada de eficácia "ex tunc", como sucede com os julgamentos proferidos em sede de fiscalização concentrada (RTJ 87/758 - RTJ 164/506-509 - RTJ 201/765), detém-se ante a autoridade da coisa julgada, que traduz, nesse contexto, limite insuperável à força retroativa resultante dos pronunciamentos que emanam, "in abstracto", da Suprema Corte. (RE n. 592.912, AgR, Rel. Min. Celso de Mello, $2^{\text {a }}$ Turma, DJe: 21 nov. 2012, publicado em: 22 nov. 2012, grifos do original)

Nessa perspectiva, com a incidência da coisa julgada, deve-se distinguir entre os planos normativos abstrato e concreto, destacando que a declaração de inconstitucionalidade opera no primeiro. Assim, a produção de efeitos retroativos não tem o condão de desconstituir a norma concreta em sentido contrário protegida a coisa julgada.

Por isso, a única solução que nos parece razoável e em pleno acordo com o ordenamento jurídico brasileiro é a proposta defendida no tópico anterior, no sentido de que deve ser proposta ação nos termos do art. 505, inciso I, do NCPC, demonstrando a alteração nos estados de fato ou de direito que justifique que a relação jurídica não mais se submeta ao regime jurídico definido pela decisão judicial que foi objeto da coisa julgada.

(MENDES, João de Castro. Caso julgado, poder judicial e Constituição. Revista da Faculdade de Direito da Universidade de Lisboa, v. 26, 1985, p. 49).

29 BARROSO, Luís Roberto. O controle de constitucionalidade no direito brasileiro: exposição sistemática da doutrina e análise crítica da jurisprudência. 2. ed. São Paulo: Saraiva. 2006. 


\section{CONSIDERAÇÕES FINAIS}

Para fazer uma síntese do que acabamos de expor, entendemos que:

i. A decisão do STF em sentido contrário ao que já havia sido definido em um caso concreto, por decisão judicial objeto da coisa julgada, não autoriza o ajuizamento de ação rescisória, por violação ao princípio da segurança jurídica.

ii. Nas relações continuativas, havendo posterior decisão do STF em sentido contrário ao comando da decisão judicial que foi objeto da coisa julgada, deve ser proposta uma ação revisional nos termos do art. 505, inciso I, do NCPC demonstrando a alteração nos estados de fato ou de direito que justifique que a relação jurídica não mais se submeta ao regime jurídico definido pela decisão judicial que foi objeto da coisa julgada.

iii. As decisões do STF em controle concentrado, que operam efeitos no plano abstrato, não têm aptidão para desconstituir as decisões judiciais objeto de coisa julgada, que operam efeitos no plano concreto. 
